\title{
Pengaruh Model Pembelajaran Two Stay Two Stray Berbantuan Media Video Terhadap Hasil Belajar IPS
}

\author{
Rizka Maulidia ${ }^{1}$, Ni Ketut Suarni ${ }^{2}$ I Komang Sujendra Diputra ${ }^{3}$ \\ ${ }^{123}$ Jurusan Pendidikan Guru Sekolah Dasar \\ Fakultas Ilmu Pendidikan \\ Universitas Pendidikan Ganesha \\ Singaraja, Indonesia \\ e-mail: rizka727@ymail.com ${ }^{1}$,niketut.suarni@undiksha.ac.id ${ }^{2}$, \\ komangsujendra.diputra@undiksha.ac.id ${ }^{3}$
}

\begin{abstract}
Abstrak
Permasalahan rendahnnya hasil belajar IPS yang diduga karena dalam proses pembelajaran cenderung masi berpusat pada guru. penelitian ini bertujuan untuk mengetahui pengaruh model pembelajaran two stay two stray berbantuan media video terhadap hasil belajar IPS siswa kelas V SD Gugus IV Desa Cupel Kecamatan Negara Kabupaten Jembrana. Populasi penelitian ini adalah seluruh siswa kelas V di gugus IV Desa Cupel Kecamatan Negara Kabupaten Jembrana. Sampel dalam penelitian ini sebanyak 2 kelas, yaitu kelas eksperimen dan kelas kontrol terdiri dari 40 orang. Pengumpulan data dilakukan dengan metode tes. Data yang diperoleh dianalisis menggunakan statistik deskriftif dan inferensial,

dengan uji-t. Berdasarkan analisis data dengan uji-t, diperoleh nilai $t^{\text {hitung }}(2,30)>t^{\text {tabel }}(2,12)$. Hala ini menandakan bahwa terdapat pengaruh yang signifikan hasil belajar ips antara kelompok yang dibelajarkan dengan menggunakan two stay two stray Berbantuan Media Video dan kelompok siswa yang dibelajarkan dengan metode konvensional pada siswa kelas $\mathrm{V}$ Gugus IV Desa CupelKecamatan Negara Kabupaten Jembrana Tahun Pelajaran 2017/2018.
\end{abstract}

Kata Kunci: hasil belajar ips, stay two stray, media video

\begin{abstract}
The problem of students low learning outcomes of social science was suspected because of in the learning process, it tended still the teacher centered. This study aimed to find out the two stay two stray learning model with the help of video media on the Social science learning outcomes of V grade students in the elementary school Gugus IV Cupel Village, Negara Sub District and Jembrana Regency. The population was all of the students of fifth grade studnets in Gugus IV Cupel Village, Negara Sub District, and Jembrana Regency. The sample of this research was 2 class, in which it was defined into experiment class and control class. Each class consisted of 40 students. The data collection was used test. The data collected were analyzed by using descriptive and inferential statistical analysis (t-test). Besed on data analysis with t-test, showed that there was a significant effect of the students' Social Science learning outcomes between the group who were taught by using two stay two stray learning model with the help of video media and the groups who were taught by using conventional methods on V grade students of Gugus IV Cupel Village, Negara Sub District and Jembrana Regency, academic year 2017/2018.
\end{abstract}

Keywords: learning Outcomes of social science, two stay two stray, video media 


\section{Pendahuluan}

Pendidikan adalah suatu usaha sadar untuk menyiapkan peserta didik melalui kegiatan bimbingan, pengajaran, dan/atau latihan peranannya di masa yang akan datang. Pendidikan merupakan bagian integral dalam pembangunan.

Proses pendidikan tak dapat dipisahkaan dari proses pembangunan itu sendiri. Pembangunan diarahkan dan bertujuan untuk membangun sumber daya manusia yang berkualitas dan pembangunan sektor ekonomi, yang satu dengan yang lainnya saling berkaitan dan berlangsung dengan bersamaan.

Bicara tentang proses pendidikan sudah tentu tak dapat dipisahkan dengan semua upaya yang harus dilakukan untuk mengembangkan sumber daya manusia yang berkualitas, sedangkan manusia berkualitas itu dilihat dari segi pendidikan, telah terkandung secara jelas dalam tujuan pendidikan nasional (Hamali, 2014). Dalam hal ini orang tua (elders) memegang peran yang sangat penting. Melalui cerita ini mereka menyampaikan berbagai pengetahuan yang menjadi dasar identitas budayanya pada semua anggota masyarakat Sudarsana, (2016). Menurut Undang-undang Republik Indonesia No. 20 Tahun 2003 tentang sistem pendidikan nasional, dimana dalan undang-undang untuk mencapai tujuan pendidikan nasioanal maka ditempuh melalaui pendidikan formal dapat dilakukan melalui pemberian mata pelajaran sebagaimana diatur pada pasal 37 ayat 1 yang menyebutkan bahwa kurikulum pada jenjang pendidikan dasar dan menengah wajib memuat 10 mata pelajaran. Salah stunya yaitu mata pelajaran Ilmu Pengetahuan Sosial (IPS).

IPS merupakan salah satu mata pelajaran pokok yang terdapat dalam kurikulum di Indosesia dan selalu berkaitan dengan jenjang pendidikan sehingga IPS perlu dikembangkan dalam setiap proses pembelajaran. Menurut S. Nution dalam Murda (2016: 04) mendefinisikan IPS sebagai pelajaran yang merupakan fusi atau paduan sejumlah mata pelajaran sosial.Dinyatakan bahwa IPS merupakan bagian kurikulum sekolah yang berhubungan dengan peran manusia dalam masyarakat yang terdiri atas bagian subjek sejarah, ekonomi, geografis, sosiologi, antropologi dan pisikologi sosial.

Pendidikan IPS diharapkan dapat menjadi wahana bagi peserta didik dan lingkungan sekitar.Tujuan utama pembelajaran IPS ialah untuk mengembangkan potensi peserta didik agar peka terhadap masalah sosial yang terjadi di masyarakat, memiliki sikap mental positif terhadap perbaikan segala ketimpangan yang terjadi, dan terampil mengatasi setiap maslah yang terjadi sehari-hari baik yang menimpa dirinya sendiri maupun yang menimpa masyarakat. Nur Hadi dalam Ahmad Susanto (2013: 146)

Hasil belajar IPS adalah perubahan yang terjasi pada diri siswa menjadi lebih baik yang mampu menguasai aspek kognitif, efektif, dan psikomotor di bidang ekonomi, psikologi, budaya, sejarah maupun politik. Dengan adanya perubahan yang terjadi pada siswa tujuan yg ingin dicapai dari hasil belar IPS yaitu pemahaman konsep tentang ilmu-ilmu soaial sehingga melekat didalam diri siswa yang bukan hanya dengan hafalan semata.

Oleh karna itu, banyak unsur yang terkait dalam pendidikan, maka tidaklah mengherankan apabila dalam proses pendidikan pada umumnya, dan pembelajaran pada khususnya, sering pula muncul beragam masalah. Masalah tersebut dapat muncul dari kesalahan oknum pendidik itu sendiri atau mungkin pula perkembangan karena yang waktu yang bergulir cepat yang beriringan dengan tantangan jaman yang berbeda dengan waktuwaktu sebelumnya. Dalam suatu pembelajaran khususnya mata pelajaran IPS sering kali dianggap membosankan oleh siswa karena dalam pembejaran ini sering kali guru hanya menggunakan metode ceramah dan menuntut siswa agar mampu menghafal dari apa yang telah diajarkan sehingga kurang menarik perhhatian siswa dalam mengikuti pembalajaran yang mengakibatkan rendahnya hasil belajar siswa.

Berdasarkan hasil wawancara dan observasi yang dilakukan pada tanggal $18-12$ desember 2018 dengan wali kelas V, yang dilakukan di Gugus IV Cupel, rata-rata niali UAS pelajaran IPS dengan niali tertinggi 80 dan niali terendah 62 dengan KKM 75 dapat dikatakan bahwa hasil belajar belum tuntas. Hal tersebet dapat diketahui dari nilai rata-tata ulangan akhir semester I IPS seperti tabel1.1 
Tabel 1.Rata-rata nilai UAS dan KKM Siswa Kelas V Sekolah Dasar Gugus IV Desa Cupel Kecamatan Negara Kabupaten Jembrana Tahun Pelajaran 2017/2018.

\begin{tabular}{ccccc}
\hline No. & Nama Sekolah & Jumlah Siswa & KKM & Rata-Rata Nilai \\
\hline 1 & SD Negeri 1 Cupel & 20 & 72 & 62,15 \\
2 & SD Negeri 2 Cupel & 20 & 72 & 63,6 \\
3 & SD Negeri 1 Tegal Badeng Barat & 22 & 72 & 63,3 \\
4 & SD Negeri 2 Tegal Badeng Barat & 29 & 75 & 71,3 \\
\hline
\end{tabular}

Sumber: wali kelas V sekolah dasar gugus IV Cupel

Hasil Studi dokumen dapat disimpulkan bahwa hasil belajar IPS di SD Gugus IV Cupel masih rendah dan perlu adanya perbaikan dalam proses pembelajaran dan hasil belajar siswa yang belum maksimal tentu berbanding lurus dengan rendahnya tingkat pemahaman dan pengusaan materi siswa terhadap muatan materi IPS. Kuarang disiplinya siswa dalam mengikuti pembelajaran terlihat sangat jelas ketika peneliti melakukan observasi, misalnya: (1) siswa yang asik sendiri dalam proses pembelajaran, (2) siswa yang tidak bisa diam di tempat duduk, (3) siswa yang melamun pada saat pembelajran berlangsung, (4) keterbatasan fasilitas pembelajaran, (5) membuat kegaduhan serta keluar masuk kelas, (6) siswa yang bosan ketika mendengarkan materi sejarah. Dimana penyebab dari siswa diatas yaitu (1) guru yang yang belum menggunakan model pembelajaran yang inovatif, (2) guru yang fokus kemateri dan tidak memperhatikan siswa. Sussana seperti ini sangat kurang mendukung proses pembelajaran sehingga mempengaruhi rendahnya penguasan kompetensi pengetahuan khususnyya mata pelajaran IPS.

Hal ini mengakibatkan peserta didik jenuh dan bosan bahkan tidak bisa konsentrasi dalam mengikuti pembelajaran sehingga dapat menyebabkan menurunnya minat belajar.Materi yang telalu banyak juga dapat menyebabkan siswa malas untuk mempelajarai materi tersebut metode yang kurang tepat dan bersifat monoton juga dapat mempengaruhi minat belajar peserta didik. Selain itu siswa kurang bersemangat dalam mengikuti proses pembelajaran yang disebabkan oleh beberapa faktor internal dan eksternal siswa. Faktor-fator tersebut mempengaruhi prosel belajar.

Hal ini mengakibatkan peserta didik merasa jenuh atau bosan bahkan tidak bisa konsentrasi dalam mengikuti pembelajaran sehingga dapat menyebabkan menurunnya minat belajar. Materi yang terlalu banyak juga dapat menyebabkan siswa malas untuk mempelajari materi tersebut.Metode yang kurang tepat dan monoton juga dapat mempengaruhi minat belajar peserta didik. Selain itu siswa kurang bersemangat dalam mengikuti proses pembelajaran yang disebabkan oleh beberapa faktor internal dari siswa. Faktor-Faktor yang dialami oleh siswa dan hal ini akan sangat berpengaruh terhadap proses belajar. Hal tersebut di atas tentunya dapat mengakibatkan para siswa akan merasa jenuh dan menganggap bahwa pelajaran IPS itu membosankan.

Berdasarkan pemaparan tersebut, tampaknya dibutuhkan suatu pola atau model pembelajaran yang mampu menjembatani tercapainya tujuan pembelajaran sesuai tuntutan kurikulum yang diterapkan.Kemampuan dan keterampilan guru dalam memilih dan menggunakan berbagai model pembelajaran senantiasa terus ditingkatkan agar pembelajaran IPS benar-benar mampu mengkondisikan upaya pembekalan kemampuan dan keterampilan dasar bagi siswa.

Model pembelajaran yang dapat diterapkan dengan mengintegrasikan elemen-elemen pendekatan santifik dalam pembelajaran yaitu, pembelajaran yang dapat membuat siswa menjadi aktif, konstektual, memecahkan masalah serta siswa yang membangun pengetahuannya sendiri. Model pembelajaran kooperatif tipe Two Stay two stray (TSTS) merupakan sebuah model pembelajaran yang menuntut siswa untuk bekerja sama dalam sebuah tim untuk mengatasi suatu permasalahan yang diberikan, guna mencapai tujuan yang sama. Dalam model pembelajaran kooperatif tipe TSTS siswa diajak untuk bisa saling bergotong-royong dalam menemukan suatu konsep. Penggunaan metode ini akan mengarahkan siswa untuk aktif baik dalam berdiskusi, tanya jawab, mencari jawaban, menjelaskan dan juga menyimak materi yang dijelaskan oleh teman.

Model pembelajaran tipe ini memberikan kesempatan kepada siswa untuk berperan aktif dalam proses pembelajaran. Tidak hanya aktif menyumbangkan gagasan di dalam kelompoknya, namun ia harus mampu menyampaikan gagasan dihadapan kelompok lain maupun kelompok sendiri. Tipe TSTS ini menuntut siswa untuk memahami penyelesaian masalah yang diberikan dan mencari informasi dari kelompok lain mengenai kesempatan atau 
perbedaan jawaban yang telah diperoleh kelompoknya. Selain itu, untuk menyelesaikan masalah yang belum terpecahkan di kelompoknya Ngalimun, (2016)

Berdasarkan hasil penelitian dan pembahasan yang dilakukan Herawati (2015) dan Arlinda (2017) dengan menggunakan model pembelajaran kooperatif tipe Two Stay Two Stray adalah sebagai berikut: (1). Aktivitas guru mengalami peningkatan dari siklus I sampai ke siklus III. (2). Aktivitas siswa mengalami peningkatan dari siklus I sampai ke siklus II. (3). Hasil belajar siswa mengalami peningkatan seara klasikal dan individual. Hal ini dikarenakan penggunaan model pembelajaran kooperatif tipe Two Stay Two Stray telah melibatkan siswa belajar secara aktif dan meningkatkan pemahaman mereka terhadap materi yang diajarkan.

Megayani (2017) Hasil penelitian Model pembelajaran Kooperatif tipe Two Stay Two Stray merupakan salah satu model pembelajaran yang tepat yang digunakan oleh Guru dalam proses belajar mengajar. Penggunaan model pembelajaran Kooperatif tipe Two Stay Two Stray terbukti telah membantu kegiatan pembelajaran peserta didik menjadi lebih menarik dan menyenangkan sehingga dapat menumbuhkan minat dan motivasi dalam belajar peserta didik serta membuat peserta didik menjadi interaktif dan komunikatif. Terdapat adanya peningkatan hasil belajar yang signifikan. Hal yang sama juga diperoleh dari hasil penelitian yang dilakukan oleh Sumarni (2017) yang menyatakan bahwa model pembelajaran kooperatif Two Stay Two Stray lebih efektif untuk meningkatkan hasil belajar peserta didik dibandingkan dengan metode konvensional.

Jika dipadukan dengan media video, siswa akan terbantu dalam memahami konsepkonsep yang tidak dapat terwakilkan dengan melalui verbal saja. Media video dirasa cocok digunakan untuk membantu menggambarkan konsep ataupun materi dalam pembelajaran IPS yang sulit dipahami tanpa dibantu dengan media pembelajaran untuk memahaminya.Misalnya pada materi Negara-negara tetangga Indonesia.Salah satu karakteristik atau kelebihan dari penggunaan media video. Yudhi Munadi (2011:127)

Adapun kaitan antara two stay-two stray (TSTS) dengan media video yaitu pembelajaran two stay-two stray (TSTS) merupakan pembelajaran mencari informasi ke kelompok-kelompok lain, sehingga menciptakan proses pembelajaran yang menarik dan hidup. Media video mampu memperjelas hal-hal abstrak dan memberikan gambaran yang realistik. Selain itu video juga sangat baik menjelaskan suatu proses pembelajaran.

Berdasarkan dari permasalahan di atas, peneliti tertarik untuk penelitian yang berhubungan dengan model pembelajaran yang dapat membuat peserta didik dalam memecahkan masalah dan menggali pengetahuan sendiri dalam mata pelajaran IImu Pengetahuan Sosial. Penelitian ini berjudul "Pengaruh Model Pembelajaran Two Stay - Two Stray (TS-TS) Berbantuan Media Video Terhadap Hasil Belajar IPS Siswa Kelas V Sekolah Dasar Gugus IV Desa Cupel Kecamatan Negara Kabupaten Jembrana Tahun Pelajaran 2017/2018".

\section{Metode}

Penelitian ini dilaksanakan di SD Gugus IV Desa Cupel Kecamatan Negara Kabupaten Jembrana. Jenis penelitian ini penelitiannon equivalent post-test onlycontrol group design, karena tidak semua variabel yang muncul dalam kondisi eksperimen dapat diatur dan dikontrol secara ketat selama 24 jam

Tabel 2. Desai Penelitian

\begin{tabular}{ccc}
\hline Kelompok & Perlakuan & Post-test \\
\hline Eksperimen & $\mathrm{X}_{1}$ & $\mathrm{O}_{1}$ \\
Kontrol & - & $\mathrm{O}_{2}$ \\
\hline
\end{tabular}

(Sumber: dimodifikasi dari Gall, et al. dalam Agung, 2014:163)

Populasi dalam penelitian ini adalah seluruh siswa kelas V Gugus IV Desa Cupel Kecamatan Negara Kabupaten Jembrana tahun peelajaran 2017/2018. Populasi penelitian sebelum mendapat perlakuan dan sebelum dipilih sebagai untuk dijadikan sampel harus dilakukan uji kesetaraan terlebih dahulu agar dapat diketahui seluruh sekolah dalam Gugus IV Cupel Kecematan Negara sudah setara. Uji yang digunakan untuk melihat kesetaraan tersebut menggunakan uji analisis ANAVA A. Dan nilai yang digunakan adalah nilai hasil UAS IPS kelas V di Gugus IV Cupel Kecematan Negara. 
Setelah dilakukan uji analsis ANAVA A, jika $F_{\text {hitung }}$ lebih kecil dari pada $F_{\text {tab }}$, untuk taraf signifikansi $5 \%$ maka $\mathrm{H} 0$ diterima dan $\mathrm{H} 1$ ditolak. Berdasarkan hasil analisis dengan ANAVA A pada taraf signifikansi $5 \%$, diperoleh nilai $F_{\text {hit }}$ sebesar 0,03 sedangkan nilai $F_{\text {tab }}$ pada $\mathrm{db}_{\text {antar }}=3$ dan $\mathrm{db}_{\text {dal }}=90$ yaitu diperoleh $F_{\text {tabel }}$ sebesar 2,28. Dengan demikian, maka terlihat $F_{\text {hit }}<F_{\text {tab }}$ $(0,03<2,28)$, sehingga $\mathrm{H} 1$ ditolak dan $\mathrm{H} 0$ diterima. Dengan kata lain, hasil belajar IPS siswa kelas V Gugus IV Desa Cupel Kecamatan Negara Kabupaten Jembrana tahun peelajaran $2017 / 2018$ adalah setara

"teknik yang digunakan mengambil sampel dari populasi disebut 'teknik sampling' " Ali (dalam Agung, 2014) tknik sampling yang akan digunakan dalam penelitian ini adalah teknik Simple Random Sampling yang dirandom adalah kelas V.

Dari lima sekolah dasar yang ada di Gugus IV Desa Cupel Kecamatan Negara Kabupaten Jembrana, dilalukan dua kali pengundian. Pengundian tahap pertama untuk memilih dua kelas yang dijadikan sampel penelitian, dua kelas yang muncul langsung dipilih sebagai kelas sampel. Kedua kelas yang terpilih menjadi sampel kemudian diundi kembali untuk menentukan kelompok eksperimen dan kontrol. Sampel yang tepilih sebagai kelas eksperimen dan kelas kontrol . berdasarkan undian yang dilakukan, kelas V SDN 2 Cupel yang berjumlah 20 orang muncul pertama dan dijadikan kelompok eksperimen dan kelas V SDN 1 Cupel yang berjumlah 20 orang muncul kedua dan dijadikan sebagai kelas kontrol.

Intrumen yang digunakan untuk memperoleh data tentang hasil belajar siswa dalam penelitian ini berupa tes pilihan ganda. Tes hasil belajar digunakan pada post-tes. Soal pilihan gangga yang digunakan sebagai instrumen berjumlahh 35 butir soal, lengkap dengan kisi-kisi soal. Sebelum tes hasil belajar IPS dipakai sebagai post-tes terlebih dahulu dilaksanakan pengujian validitas konstruk instrumen kepada pakar, kemudian dilakukan uji coba soal pada kelas $\mathrm{V}$ di sekolah tempat penelitian.

Selanjutnya dilakukan analisis hasil uji coba soal diataranya uji validitas, reabilitas, tingkat kesukaran dan daya beda tes. Setelah melaksanakan pengujian tersebut, diperoleh sebanyak 30 soal yang layak digunakan dalam post-test dan sesuai dengan kisi-kisi merupakan deskripsi mengenai ruang lingkup materiyang akan diujikan dengan tujuan memperoleh petujuk yang efektif dalam penyusunan tes. Setiap soal disertai dengan empat alternative jawaban yang dipilih oleh siswa (alternative a, b, c, dan d) setiap jawaban benar diberi skor 1 (jawaban dicocokan dengan kunci jawaban) seta skor 0 untuk siswa yang menjawab salah dan tidak hadir pada saat tes. Pengujian instrumen penelitian dilakukan untuk mendapat gambaran secara empirik mengenai layak tidaknya instrumen tersebut digunakan sebagai instrumen penelitian. Syarat intrumen penelitian yang diuji dalam penelitian ini adalah validitas tes, reabilitas tes, tingkat kesukaran tes dan daya beda tes. Berdasarkan perhitungan paliditas isi intrumen diperoleh indeks validitas isi sebesar 1,00. Maka, kontens instrumen tersebut dikatakan valid. Berdasarkan analisis validitas tes hasil belajar IPS dengan menggunakan program Microsoft office excel 2007, dari 43 soal yang diujicobakan diperoleh hasil yaitu 37 butir yang valid dan 6 butir yang tidak valid. Instrumen tes hasil belajar IPS yang digunakan adalah item dengan status butir valid dan untuk butir tidak valid tidak digunakan. Analisis perhitungan tes reliabilitas tes hasil belajar IPS menggunakan program Microsoft office excel 2007. Berdasarkan perhitungan terhadap 37 butir soal diperoleh reliabilitas keseluruhab butir tes sebesar 0,89, sehingga dapat disimpulkan bahwa intrumen hasil belajar IPS memiliki reliabilitas sangat tinggi. Nalisisi perhitungan taraf kesukaran tes hasil belajar IPS pada tingkat kesukaran mudah. Secara keseluruhan perangkat tes berada pada tingkat kesukaran 0,50yang artinya berada kriteria sedang. Berdasarkan hasil uji daya beda tes yang dibantu dengan program Microsoft office excel 2007, Dp = 0,21 sehingga perangkat yang digunakan termasuk cukup baik.

Analisis data dilakukan semua data dikumpulkan. Metode analisis data yang digunakan untuk menganalisis data hasil belajar adalah analisis deskriptif dan analisisi inferensisal. Analisis stratistik deskriptif digunakan untuk mendeskripsikan data hasil belajar IPS siswa yang dibelajarkan dengan menggunakan model pembelajaran two stay two stray (TSTS) berbantuan media video dan data hasil belajar IPS siswa yang tidak dibelajarkan menggunakan model pembelajaran two stay two stray (TSTS) berbantuan media video. Analisis deskriptif digunakan untuk mengetahui tinggi rendahnya kualitas dari dua variabel yaitu model pembelajaran dan hasil belajarsiswa. Statistik inferensial digunakan untuk menguji kebenaran hipotesis penelitian. Menurut Agung (2016) "statistik deskripsi berfungsi untuk menjadikan data bermakna, yang diantaranya dapat disajikan menggunakan ukuran tendensi sentral (mean, median, modus) dan standar deviasi". hal ini menunjukan betapa perlunya menentukan ukuran tendensi dan standar deviasi setiap kelompok data variabel. Pada penelitian ini, uji hipotesis menggunakan uji-t. 
Menurut Koyan (2012) "uji-t berfungsi untuk menguji perbedaan nilai-nilai antara dua kelompok eksperimen dan kelompok konrtrol. Sebelum melakukan uji t, dilakukan uji asumsi dan uji prasyrat terlebih dahulu. Adapun uji asumsi dan uji prasyat yang dimiliki uji-t adalah uji normalitas sebaran data dan ji homogenitas varians, Agung (2016).

\section{Hasil dan Pembahasan}

Deskripsi hasil data penelitian ini meliputi deskripsi data hasil post-test kelompok eksperimen dan deskripsi data hasil post-test kelompok kontrol. Data hasil penelitian yang dianalisis di kelas V Gugus IV Desa CupelKecamatan Negara Kabupaten Jembrana pada semester genap Tahun Pelajaran 2017/2018, yang dilakukan sebanyak 7 kali pertemuan, 6 kali pertemuan kegiatan pembelajaran dan 1 kali pertemuan untuk melakukan post-test.

Bedasarkan tes hasil belajar IPS yang diberikan kepada kedua kelas setelah 6 kali proses pembelajran. Maka diperoleh data hasil belajar IPS dilaksanakan setelah pembelajaran (post-test) pada Tabel 3.

Tabel 3. Statistik deskriptif Hasil Penelitian

\begin{tabular}{ccc}
\hline Statistik & Kelompok Eksperimen & Kelompok Kontrol \\
\hline Banyak sampel & 20 & 20 \\
Mean & 21,25 & 18 \\
Median & 20,83 & 18 \\
Modus & 22,50 & 18,21 \\
Standar deviasi & 3,73 & 4,50 \\
Vaeians & 13,94 & 20,22 \\
Skor maksimum & 28 & 26 \\
Skor minimum & 15 & 11 \\
Rentangan & 13 & 15 \\
\hline
\end{tabular}

Berikut grafik polygon kelas eksperimen

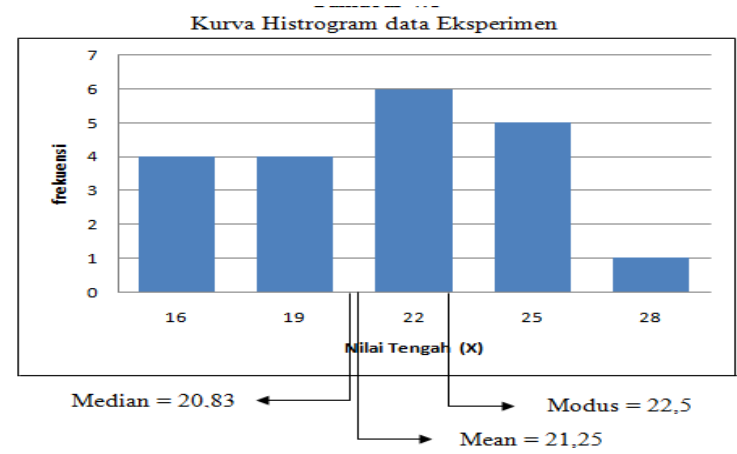

Gambar Kurva histrogram Data Eksperimen

Berdasarkan grafik Polygon Data hasil belajar IPS kelompok eksperimen dapat diketahui modus lebih besar dari median dan median lebih kecil dari mean (Mo $>M d<M)$. Dengan kata lain, adalah kurva juling negatif. Artinya, sebagian besar besar sekor cenderung sangat tinggi. Berikut grafik polygon kelas eksperimen 


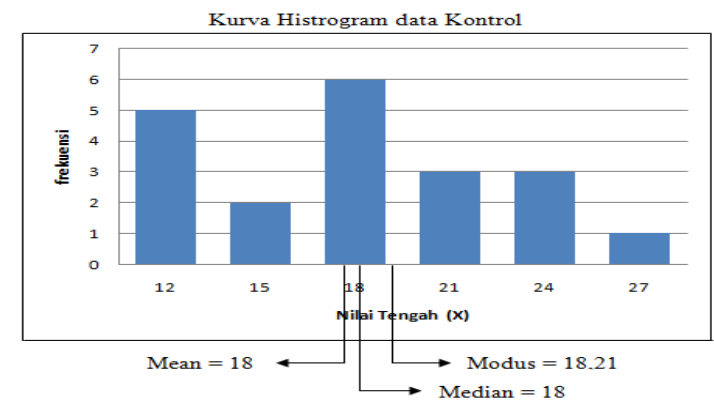

Gambar Kurva histrogram Data Kontrol

Berdasarkan grafik Polygon Data hasil belajar IPS kelompok kontrol modus lebih besar dari median dan median lebih sama dengan mean (Mo>Md=M). Dengan kata lain, adalah kurva juling negatif. Artinya, sebagian besar besar sekor cenderung tinggi.

Uji prasarat dilakukan untuk memperoleh fakta apakah data memenuhi prasyarat homogenitas varians dan normalitas data. Uji normalitas yang dilakukan pada data hasil belajar IPS kelompok eksperimen (kelompok siswa yang dibelajarkan dengan menggunakan model pembelajaran model pembelajaran two stay two stray (TSTS) berbantuan media video) yaitu di SDN 2 Cupel dengan menggunakan analisis Chi Kuadrat $\left(x^{2}\right)$. Pengujian dilakukan pada taraf signifikan $5 \%$ dengan derajat kebesaran $\mathrm{db}=$ (jumlah baris $-2-1$ ). Hasil perhitungan Chi Kuadrat $\left(x^{2}\right)$ data hasil belajar IPS pada kelompok eksperimen dan kelompok kontrol disajikan pada tabel berikut. Perhitungan ini dibantu dengan menggunakan program Microsoft office excel 2007.

Tabel 4. Hasil uji Normalitas dengan uji Chi Kuadrat $\left(x^{2}\right)$

\begin{tabular}{lllll}
\hline Kelas & $\mathrm{X}^{2}$ hitung & & $\mathrm{X}^{2}$ tabel & Keterangan \\
\hline Eksperimen & 1,60 & $<$ & 5,591 & Normal \\
Kontrol & 7,51 & $<$ & 7,92 & Normal \\
\hline
\end{tabular}

Setelah data dinyatakan berdistribusi normal, maka selanjutnya dilakukan uji homogenitas.Uji homogenitas varians ini dilakukan dengan uji Fisher.Uji homogenitas dilakukan untuk mengetahui apakah kedua varians data bersifat homogen. Dari hasil perhitungan yang

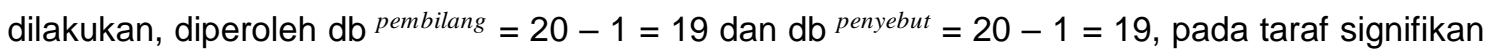

$5 \%$ diketahui $\mathrm{F}^{\text {tabel }}=2,12>\mathrm{F}^{\text {hitung }}=1,45$. Sehinggga $\mathrm{H}^{0}$ diteriman dan $\mathrm{H}^{1}$ ditolak. Jadi varians kelompok eksperimen dan kontrol adalah homogen.Berdasarkan hasil uji normalitas dan homogenitas di atas, dapat disimpulkan bahwa persyaratan untuk pengujian hipotesis dengan menggunakan uji-t untuk sampel independen (tidak berkolerasi) dapat dipenuhi.

Pengujian hipotesis dalam penelitian ini menggunakan uji-t dengan rumus rumus polled varians. Data yang digunakan yaitu skor rata-rata $\left(\overline{\mathrm{X}}_{1}\right)$ kelompok eksperimen sebesar 21,25dengan varians $\left(\mathrm{s}_{1}{ }^{2}\right)$ sebesar 13,94, $\left({ }^{n}\right)$ jumlah sampel sebesar 20. Pada kelompok kontrol diperoleh skor rata-rata $\left(\bar{X}_{2}\right)$ sebesar 18,00dengan varians $\left(\mathrm{s}_{2}{ }^{2}\right)$ sebesar 20,22, $n_{2}$ jumlah sampel sebesar 20.

Hasil perhitungan setelah dilakukan analisis menggunakan uji-t, maka hasil perhitungan uji-t di atas, di peroleh t hitung sebesar 2,30. Sedangkan t tabel pada taraf signifikan $5 \%$ cara mencari yaitu $\mathrm{n} 1=20-1=19$ maka t tabelnya 2,09 sedangkan $\mathrm{n} 2=20-1=19$ maka t tabel 2,09. Kemudian selisihnys dibagi dua, $(2,09-2,09): 2=0$, kemudian ditambah dengan harga $t$ tabel terkecil, 2,09 , sehingga menjadi $2,09+0=2,09$. Tenyata t hitung didapatkan dengan harga $2.30>$ dan t tabel 2,09. Sehingga $\mathrm{H} 0$ diterima dan $\mathrm{H} 1$ ditolak. Hal ini menunjukan hasil belajar IPS siswa yang dibelajarkan dengan model pembelajaran two stay two stray (TSTS) berbantuan media video lebih baik daripada hasil belajar IPS siswa yang tidak dibelajarkan dengan model pembelajaran two stay two stray (TSTS) berbantuan media video. 
Tabel 5. Hasil Uji Hipotesis dengan Uji-t

\begin{tabular}{cccccc}
\hline Kelompok & $\mathrm{N}$ & Mean & $\mathrm{s}^{2}$ & $\mathrm{t}^{\text {hitung }}$ & $\mathrm{t}^{\text {tabel }}$ \\
\hline Kelompok Eksperimen & 20 & 21,25 & 13,94 & \multirow{2}{*}{2,30} & \multirow{2}{*}{2,09} \\
Kelompok Kontrol & 20 & 18 & 20,22 & & \\
\hline
\end{tabular}

Dari Tabel diatas dapat besimpulka bahwa terdapat pengarung hasil belajar IPS yang signifikan antara siswa kelas $\mathrm{V}$ yang mendapat perlakuan model pembelajaran two stay two stray (TSTS) berbantuan media video dan siswa kelas model pembelajaran two stay two stray (TSTS) berbantuan media video.

Sebelum dilakukan uji hipotesis dengan menggunakan analisis uji-t, terlebih dahulu dilakukan uji prasyarat yang meliputi uji normalitas sebaran data dan uji homogenitas varians.Dari hasil perhitungan diketahui bahwa sebaran data pada kedua kelompok berdistribusi normal dan memiliki varins yang homogen.Karena data pada kelompok eksperimen dan kelompok kontrol telah memenuhi semua prasyarat, selanjutnya dilakukan analisis dengan mengunakan uji-t.

Hasil perhitungan setelah dilakukan analisis menggunakan uji-t, maka diperoleh nilai $t_{\text {hitung }}$ sebesar 2,30. Nilai $t_{\text {tabel }}$ taraf signifikansi $5 \%$ diperoleh nilai $t_{\text {tabel }}=2.09$. Dengan membandingkan nilai $t_{\text {hitung }}$ dan $t_{\text {tabel }}$ diperoleh perbandingan $t_{\text {hitung }}>t_{\text {tabel }}$, ini menunjukan berarti $\mathrm{H}_{0}$ ditolak dan $\mathrm{H}_{1}$ diterima. Hal ini menunjukan hasil belajar IPS siswa yang dibelajarkan model pembelajaran model pembelajaran two stay two stray (TSTS) berbantuan media video lebih baik dari pada hasil belajar IPS siswa yang tidak dibelajarkan dengan model pembelajaran two stay two stray (TSTS) berbantuan media video.

Menurut Aris Sohimin (2016: 222) adapun keliebihan dan kekurangan model pembelajaran TSTS (two stay two stray) sebagai berikut. 1). Adapun kelebihan dari model TSTS adalah sebagai berikut. a). Dapat diterapkan pada semua kelas/tingkatan; b). Kecenderungan belajar siswa menjadi lebih bermakna; c). Lebih berorientasi pada keaktifan; d). Diharapkan siswa akan berani mengungkapkan pendapatnya; e). Menambah kekompakan dan rasa percaya diri siswa; f).Kemampuan berbicara siswa dapat ditingkatkan; g).Membantu meningkatkan minat dan prestasi belajar. 2). Sedangkan kekurangan dari model TSTS yaitu: a). Membutuhkan waktu yang lama; b). Siswa cenderung tidak mau belajar dalam kelompok; c). Bagi guru, membutuhkan banyak persiapan (materi, dana dan tenaga); d). Guru cenderung kesulitan dalam pengelolaan kelas.

Untuk mengatasi kekurangan model pembelajaran kooperatif tipe TSTS, maka sebelum pembelajaran guru terlebih dahulu mempersiapkan dan membentuk kelompok-kelompok belajar yang heterogen ditinjau dari segi jenis kelamin dan kemampuan akademis. Berdasarkan sisi jenis kelamin, dalam satu kelompok harus ada siswa laki-laki dan perempuannya. Jika berdasarkan kemampuan akademis maka dalam satu kelompok terdiri dari satu orang berkemampuan akademis tinggi, dua orang dengan kemampuan sedang dan satu lainnya dari kelompok kemampuan akademis kurang. Pembentukan kelompok heterogen memberikan kesempatan untuk saling mengajar dan saling mendukung sehingga memudahkan pengelolaan kelas karena dengan adanya satu orang yang berkemampuan akademis tinggi yang diharapkan bisa membantu anggota kelompok yang lain

Penelitian ini dipertegas oleh penelitian yang dilakukan Luh komang Laksmi Prasetya (2017) penelitian yang berjudul penelitian yang berjudul "pengaruh model pembelajaran two stay two stray (TSTS) berbasis masalah terhadap hasil belajar IPA siswa kelas $\mathrm{V}$ di gugus IV kecamatan Banjar tahun pelajaran 201/2017". Hasil penelitian menunjukan 1) keaktifan belajar siswa yang model pembelajaran kooperatif tipe TSTS berbasis masalah lebih baik dari pada siswa yang mengikuti model pembelajaran konvensional, 2) prestasi belajar IPA siswa yang mengikuti model pembelajaran kooperatif tipe TSTS berbasis masalah lebih baik dari pada siswa yang mengikuti model pembelajaran konvensional, 3) secara simulatif, keaktifan, dan prestasi belajar IPA siswa yang mengikuti model pembelajaran kooperatif tipe TSTS berbasis masalah lebih baik dari pada siswa yang mengikuti model pembelajaran konvensional.

\section{Simpulan dan Saran}

Berdasrkan hasil penelitian terdapat perbedaan yang signifikan antara siswa yang dibelajarkan dengan Model Pembelajaran model pembelajaran two stay two stray (TSTS) berbantuan media video dengan siswa yang dibelajarkan dengan model pembelajaran 
konvensional Terhadap Hasil Belajar IImu Pengetahuan Sosial Siswa Kelas V Sekolah Dasar Gugus IV Desa Cupel Kecamatan Negara Kabupaten Jembrana Tahun Pelajaran 2017/2018.

Hal ini terbukti dari hasil post-test yang telah dilakukan analisis.Berdasarkan uji-t.

Dinyatakan bahwa $\mathrm{t}^{\text {hitung }}>\mathrm{t}^{\text {tabel }}$ ( $\mathrm{t}^{\text {hitung }}=2,30>\mathrm{t}^{\text {tabel }}=2,12$,) sehinggga $\mathrm{H}^{0}$ ditolak dan $\mathrm{H}^{1}$ diterima. Berdasarkan skor rata-rata hasil belajar IPS, diketahui bahwa skor rata-rata siswa kelas $\mathrm{V}$ yang menggunakan model pembelajaran two stay two stray (TSTS) adalah 21,25 (dikate gorikan tinggi), sedangkan siswa yang belajar menggunakan model konvensional adalah 18,00 (dikategorikan rendah). Hal ini berarti $(\bar{X})$ eksperimen $>(\bar{X})$ kontrol.

Berdasarkan hasil penelitian ini, maka dapat diajukan beberapa saran sebagai tindak lanjut dari penelitian ini adalah sebagai berikut.Kepada guru, disarankan untuk mengembangakan pembelajaran dengan menggunakan berbagai macam model pembelajaran dan media yang inovatif, khususnya dalam mata pelajaran IPS.Salah satu model pembelajaran two stay two stray (TSTS) berbantuan media video sehingga dapat mengoptimalkan hasil belajar IPS siswa.Kepada kepala sekolah, agar selalu mendukung penggunaan model pembelajaran yang inovatif dalam pembelajaran. Salah satunya model pembelajaran two stay two stray (TSTS) berbantuan media video sehingga siswa lebih aktif dalam proses pembelajaran. Kepada peneliti lain, untuk meneruskan penelitian ini agar mampu menjangkau masalah-masalah lain yang belum ditemukan dalam penelitian ini, sehingga menjadi penelitian yang sempurna dari penelitian ini.

\section{Daftar Pustaka}

Agung. (2014). Metodologi Penelitian Pendidikan. Malang: Aditya Media Publishing.

Agung. (2016). statistika Dasar Untuk Pendidikan. Yogyakarta: Deepublish.

Arlinda. 2017. Penerapan Model Pembelajaran Kooperatif Tipe Two Stay Two Stray (TSTS) untuk Meningkatkan Hasil Belajar IPS Siswa Kelas IV B SDN 21 Sitorajo Kecamatan Kuantan Tengah. Jurnal Primary Program Studi Pendidikan Guru Sekolah Dasar Fakultas Keguruan dan IImu Pendidikan Universitas Riau | Volume 6 | Nomor 2 | Oktober 2017

Hamali, O. (2014). Kurikukulum dan Pembelajaran . Singaraja: PT Bumi Aksara.

Herawati. 2015. Penerapan Model Pembelajaran Two Stay Two Stray Untuk Meningkatkan Prestasi Belajar Siswa pada Materi Keliling dan Luas Lingkaran Di Kelas VI SD Negeri 53 Banda Aceh. Jurnal Peluang, Volume 3, Nomor 2, April 2015

Megayani. 2017. Penerapan Model Pembelajaran Kooperatif Tipe Two Stay Two Stray (TSTS) Terhadap Hasil Belajar Siswa pada Materi Sistem Ekskresi. Jurnal Bio Education, Volume 2, Nomor 2, Oktober 2017, hlm. 27-34

Murda, \& Yudiana. (2016). Pendidikan IPS SD. Singaraja: Deepuplis.

Ngalimun. (2016). Strategi dan Model Pembelajaran. Yogyakarta: Aswaja Perssindo.

Sumarni. 2017. Penerapan Model Pembelajaran Kooperatif Two Stay Two Stray (TSTS) untuk Meningkatkan Apresiasi dan Kreasi Peserta Didik. DIADIK : Jurnal Ilmiah Teknologi Pendidikan, 7(2), 2017.

Susanto, Ahmad. (2013). Teori Belajar Dan Pembelajaran Di Sekolah Dasar.Jakarta: PT Kharisma Putra Utam 